\title{
KĀDĀ VALODĀ RUNĀ DIASPORA? VALODAS SITUĀCIJAS DINAMIKA
}

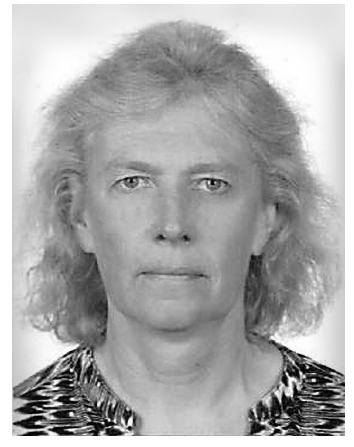

Daina Grosa ir Latvijas Universitātes Filozofijas un sociologijas institūta pētniece. Viṇas pētniecības jomas ir lietišķā valodniecība, sociolog̣ija un cilvēkǵgeogrāfija. Pētījumi veikti Latvijas diasporā par dzimtās valodas uzturēšanu diasporā, bērnu remigrāciju valsts atbalsta kontekstā, kā arī migrācijas un remigrācijas emocionālo iespaidu uz bērnu labsajūtu. Pètījumi ir publicēti valsts pētījumu zinojumos un prezentēti starptautiskās konferencēs. Maǵistra grāds lietišķajā valodniecībā iegūts Monaša (Monash) Universitātē (Austrālijā), un pašlaik notiek doktora studijas Saseksas (Sussex) Universitātē (Anglijā).
Raksturvārdi: diaspora, dzimtās valodas uzturēšana, migrācija, remigrācija, psihosociālā labsajūta.

\section{Ievads}

Kopš Latvijas valsts neatkarības atjaunošanas pirms trīs gadu desmitiem un Latvijas iestāšanās Eiropas Savienībā 2004. gadā, Latvijas valstspiederīgajiem emigrējot uz ārvalstīm, mainījusies vinu valodu prasme un valodas lietošanas tendences. Dzīvojot ārpus Latvijas lingvistiskās vides, Latvijas diasporas locekḷiem uzsākot dzīvi un integrējoties citās valstīs - strādājot, studējot un ikdienā sazinoties ar vietējiem iedzīvotājiem citā valodā -, neizbēgami jaunā mītnes zemes valoda, kā arī citas valodas, kuras nepieciešamas saziņai, diasporā tiek izmantotas pastiprināti.

Ir bijis svarīgi valodas lietošanas tendences diasporā monitorēt pētnieciskā ceḷā, lai valsts varētu atbilstoši un laicīgi reaǵēt, izstrādājot un piedāvājot diasporā mītošiem dažāda veida latviešu valodas apguves atbalsta pasākumus, kad tādi ir nepieciešami.

Pēdējos gados ir veikti vairāki pētījumi par Latvijas valstspiederīgo dzīvi diasporā, kā arī par to, kāds ir Latvijā atgriezušos remigrantu skatījums uz dzīvi. Balstoties uz datiem, kas iegūti Latvijas Universitātes Filozofijas un socioloǵijas institūta (turpmāk - LU FSI) pētnieku grupas diasporas un remigrantu pētījumos Latvijas emigrantu kopienas: nacionālā identitāte, transnacionālās attiecības un diasporas politika (2014), Atgriešanās Latvijā (2016) un nesen veiktā pētījuma Latvijas emigrantu kopienas otrajā viln̄̄ - Labklājības un sociālās integrācijas izpēte likvīdās migrācijas kontekstā: longitudinālā pieeja (2019), var izdarīt būtiskus secinājumus par valodas lietojumu Latvijas diasporā un tā dinamiku. Secinājumi jau apkopoti gan Latviešu valodas aǵentūras pētījumā Valodas situācija Latvijā 2010-2015. Sociolingvistisks pētījums, gan nupat tapušā LU FSI pētnieku zinojumā $\mathrm{Va}$ lodas situācija Latvijā: 2016-2020, un secinājumos vērts ielūkoties, tos kontekstualizējot ar pasaulē pazīstamām sociolingvistiskām teorijām, kas saistītas ar valodu, migrāciju un etniskām kopienām.

Šajā publikācijā sniegts pārskats par latviešu valodas lietošanu diasporā galvenajās mītnes zemēs, kā arī par situācijas dinamiku, 
izmantojot gan Latvijas Universitātes pētnieku apkopotos datus, gan ārējos apsekojumus. Pētijums veikts ar Latvijas Zinātnes padomes finansiālu atbalstu granta Labklājības un sociālās integrācijas izpēte likvīdās migrācijas kontekstā: longitudinālā pieeja (Nr. LZP2018/1-0042) ietvaros.

\section{Diasporas likums veidojis ietvaru}

2018. gada nogalē tika pieņemts un 2019. gada 1. janvārī spēkā stājās Latvijas Diasporas likums, lai stiprinātu Latvijas diasporas latvisko identitāti un piederību Latvijai, sekmētu latviešu valodas un kultūras saglabāšanu diasporā, kā arī atbalstītu un veicinātu diasporas pilsonisko un politisko līdzdalību. Latviešu valoda jaunajā Diasporas likumā tiek pieminēta vairākos pantos. 2. pantā nosaukti pieci likuma mērḳi, un 3. un 4. mērkis ir

3) sekmèt latviešu valodas un kultūras saglabāšanu diasporā;

4) izstrādāt un ìstenot sistēmisku un pastāvīgu diasporas atbalsta politiku un pasākumus, kuri veicina diasporas latvisko identitāti un saikni ar Latvijas kultūru, ekonomiku, tautsaimniecību un zinātni, latviešu valodas, kultūras un tradīciju pieejamību diasporai un nodrošina labvēlīgus apstāklıs remigrācijai (Diasporas likums, 2. pants (3), (4)).

Savukārt no 13 diasporas politikas uzdevumiem divi ir vērsti uz latviešu valodas apguvi, saglabāšanu, aizsardzību un attīstību diasporā. Diasporas politikas īstenošanas principos latviešu valodas saglabāšana arī skaidri iezīmēta kā viens piemērs no latviskās piederības principiem. Likumā teikts, ka Izglītības un zinātnes ministrija

f) izstrādā un ìsteno atbalsta pasākumus, kas vērsti uz latviešu valodas, arī latgaliešu rakstu valodas $k \bar{a}$ vēsturiska latvie$\check{s} u$ valodas paveida, un lībiešu valodas saglabāšanu, aizsardzību un attīstību diasporā,

g) nodrošina valsts valodas prasmes pārbaužu organizēšanu un pieejamību diasporai tās loceklu pastāvīgajās dzīvesvietās ārvalstīs, izsniedzot atbilstošu valsts valodas prasmes apliecību (Diasporas likums, 6. pants, (3)(f), (g)).
Skaidrs, ka latviešu valodai likumā pieškirta būtiska nozīme diasporā saistībā ar diasporas latvisko identitāti, valodas saglabāšanu (uzturēšanu) un apguvi (pārsvarā bērniem), un likumā ietverti atbalsta pasākumi un darbības, kas Latvijas valstij būtu jāveic, lai diasporas politikas uzdevumus varētu îstenot.

Rodas jautājums - kādās valodās tad šobrīd runā Latvijas diasporā un vai šim faktam ir jāvelta īpaša uzman̄iba? Vai ir nepieciešams runāt par pasaules valodu saglabāšanu un aizsardzību? Lai uz šo jautājumu atbildētu, vajadzīgs šì brīža "momentuzṇēmums", lai iemūžinātu valodas situāciju diasporā. Kādas valodas Latvijas diasporā dominē, un vai mainās valodu lietojums?

\section{Vēsturiskais fons, latviešu valodas statuss}

Ina Druviete (2016) ievadrakstā, veidojot ietvaru Latviešu valodas aǵentūras pētījumam par latviešu valodas situāciju no 2010. līdz 2015. gadam, raksturo valodas politikas kā sociolingvistikas nozares vēsturisko fonu. 20. gs. 60. un 70. gados tādi pētnieki kā U. Veinreihs (Weinreich), J. Gampercs (Gumperz), E. Haugens (Haugen) u. c. pievērsās pētîjumiem par valodu kontaktiem, valodu zudumu un atdzimšanu, multilingvismu, kas visi ietekmē valstu valodas politiku. Īpaši plašu ievērību guva Maikla Krausa (Michael Krauss) 1991. gadā teiktā uzruna Amerikas lingvistu biedrībai, kurā viṇš brīdināja, ka "mums acīmredzami ir nopietni jāizvērtē savas prioritātes, lai lingvistika vēsturiski nekḷūst par vienīgo zinātni, kuras vadībā nevērības dēḷ pazuda 90\% no tās jomas, kuras dēḷ tā pastāv" .

I. Druviete kā iemeslu pasaules valodu zudumam skaidro: "21. gadsimtā, kad fizisks genocīds pret kādu etnosu - valodas nesēju ir iznēēmuma parādība, galvenais iemesls ir vecāku un vecvecāku nespēja vai nevēlēšanās nodot savu valodu nākamajām paaudzēm."2 Ietekmējošo faktoru ir daudz, un tie ir dažādi, bet viens no galvenajiem, kas veicina lingvistisko asimilāciju, ir intensīvā urbanizācija. Pēc Dž. Fišmena (Joshua Fishman) paaudžu

\footnotetext{
1 Krauss 1992, 10.

2 Druviete 2016, 16.
} 
lingvistiskās pēctecības skalas (Graded Intergenerational Disruption Scale - GIDS), latviešu valodā 2015. gadā runāja vismaz 2 miljoni cilvēku un tā raksturojama kā 1. līmeņa nacionālā valoda, tātad latviešu valoda šobrīd skaitās neapdraudēta. Skaitliski 2015. gadā Latvijā dzīvoja 1 miljons 979,4 tūkstoši iedzīvotāju, bet aptuveni 370000 latviešu mît diasporas valstīs (t. i., dzīvo ārpus Latvijas) ${ }^{3}$.

Lai gan latviešu valoda neskaitās apdraudēta (valodas, kuru runātāju skaits pārsniedz 1 miljonu, tiek ierindotas absolūti drošo valodu grupā), tomēr ir jāṇem vērā tas, ka ar latviešu valodu Latvijas lingvistiskajā telpā konkurē angḷ un krievu valoda - divas no sešām starptautiskajām megavalodām -, kā arī uz valodas dzīvotspēju negatīvu ietekmi atstāj fakts, ka ārpus Latvijas valsts dzīvojošie piedzīvo dinamisku valodas situāciju, kurā, dzīvojot diasporā, spiediens uz valodas asimilāciju ir liels.

Tomēr kopumā latviešu valodas etnolingvistiskā vitalitāte arī vērtējama kā augsta, toties, skatoties uz lingvistisko attieksmi pret savu valodu, - uz vienu no kritērijiem valodas noturības noteikšanai -, parādās, ka tikai vairums runātāju (bet ne visi) atbalsta valodas saglabāšanu. I. Druviete norāda, ka normatīvie regulējumi un juridiskie mehānismi nav vien̄̄gie, kas ietekmē valodas lietojumu, jo svarīgi ir atcerēties, ka "likums neattiecas uz valodu lietošanu Latvijas iedzīvotāju neoficiālajā saziņā" (Valsts valodas likums, 2(3). dalia), un "līdz ar to jāatzīst, ka tieši subjektīvais faktors jeb lingvistiskā attieksme latviešu etnolingvistisko vitalitāti neḷauj atzìt par atbilstīgu valodu konkurences situācijai”"4.

\section{Dzimtās valodas pētniecība pasaulē}

R. Lī (Lee) (2018), pētot imigrantus Kanādā un viṇu pēcteču dzimtās valodas (mother tongue) prasmju uzturēšanu, uzsver, ka tā ir cieši saistîta ar viṇu nacionālo un etnisko identitāti un imigrantu integrāciju. Vēsturiski teorētiskā tradīcija un pieeja imigrantu un viņu pēcteču valodas saskarsmei un apguvei galvenokārt ir bijusi vērsta uz pāreju no dzimtās valodas prasmēm uz jaunās mītnes

\footnotetext{
3 Druviete 2016, 30.

4 Turpat, 32.
}

zemes valodu ${ }^{5}$. Uzsvars uz valodas nomainu (language shift) radās ar trīs paaudžu modeli, kurā ar katru nākamo paaudzi mītnes zemes valodas prasme uzlabojas, bet dzimtās valodas prasme pasliktinās ${ }^{6}$. Saskaṇā ar šo modeli pirmā paaudze ir pārsvarā monolingvāla dzimtajā valodā ar ierobežotām mītnes zemes valodas spējām. Otrā paaudze, kura dzimusi mītnes zemē un kuras vecāki dzimuši izcelsmes valstī, ir bilingvāla dzimtajā valodā un mītnes zemes valodā (kaut vini priekšroku dod mītnes zemes valodai) ${ }^{7}$, un trešajai paaudzei, kurai vecvecāki ir dzimuši izcelsmes valstī un kura pati ir dzimusi mītnes valstī, ir tikai mītnes valsts valodas prasmes ${ }^{8}$.

Ir vairāki pētījumi, kuros apstrīd šo trīs paaudžu modeli; kur atklājas, ka plaša angḷu valodas prasmju apguve ne vienmēr nozīmē arī valodas nomaiņu uz angḷ valodu kā vienīgo valodu un dzimtās valodas pilnīgu zudumu . Tajās etniskajās kopienās, kur regulāri uz jauno mītnes valsti pārceḷas arvien jauni imigranti no izcelsmes valsts (piem., meksikānuu imigranti ASV) un kur rodas iespējas valodu pielietot saskarsmē ar citiem imigrantiem, kuri dzimto valodu runā tekoši, tur šì valodu izmaiña tik krasi arī nenotiek ${ }^{10}$. Mītnes valstī arī iespējams, ka mainījusies attieksme pret dzimtās valodas lietošanu ǵimenē un bilingvisms tiek uztverts pozitīvi, novērtējot labumu, ko tas sniedz kognitīivi un izglītojošā ziņā ${ }^{11}$.

Vērts mazliet ielūkoties jēdziena "diaspora" definīcijāa, kā arī paskatīties vēsturiski latviešu valodas lietojumā un tā dinamikā trimdā, lai gūtu ieskatu valodas situācijā, kāda izveidojusies ārpus Latvijas dzīvojošiem valsts piederīgajiem, kuri iepriekšējā izceḷošanas viln̄̄ piedzìvojuši līdzịgas izmainas valodas lietojumā.

A. Lulle (2019), runājot par jēdzienu "diaspora", skaidro, ka mūsdienās Latvijā šis jēdziens aptver "ārpus valsts teritorijas dzīvojošus Latvijas iedzīvotājus, kuri jūtas piederīgi

\footnotetext{
5 Fishman 1972; Stevens 1985.

6 Alba et al. 2002; Veltman 1983.

${ }^{7}$ Lopez 1996.

8 Fishman 1972.

9 Alba et al. 2002.

10 Linton, Jimenez 2009.

11 Alba et al. 2002; Linton, Jimenez 2009.
} 
Latvijai" ${ }^{2}$. Šs ir politiski noteikts skaidrojums, kurš politikas plānošanas dokumentos tiek lietots kopš 2010. gada, kad Kultūras ministrijas kompetencē nonāca jautājums, kā koordinēt saikṇu stiprināšanu ar diasporu. Termins gan ir akadēmiski strīdīgs, jo jēdziens ne visu pētnieku (kā arī pašu izceḷojušo) acīs attiecināms uz visiem tiem, kas izcelıjuši no kādas valsts. Bēgḷ gaitās devušos terminologíski dēvē par trimdiniekiem, un tā pati sevi identificē arī l̦aužu grupa, kas izcelıjusi no Latvijas un to atstājusi Otrā pasaules kara laikā. Ir bijuši mēginājumi atdalīt "veco trimdu" no "jaunajiem emigrantiem", kā arī "Rietumu diasporu" no "Austrumu diasporas"13. Katrai no šìm l̦aužu grupām, kas izceḷojušas no Latvijas, ir raksturīgas īpašības un vēsturisks konteksts, kas tās mazliet atškir vienu no otras, bet kopumā rezultāts ir viens - tās (te iekḷauti arī transnacionāli, kuri daḷu savu laika pavada Latvijā, daḷu ārpus Latvijas) šobrīd pārsvarā par savu dzīvesvietu izvēlas valsti, kas ir ārpus Latvijas. Neskatoties uz to, 21. gadsimtā, saskaņā ar Latvijas valsts iestāžu politiku, arī trimdinieki, Krievijā dzīvojošie latvieši un viņu pēcteči tiek dēvēti par diasporas locekliem. Tādā veidā tiek uzsvērta viṇu izcelsme un piederība Latvijai.

\section{Trimdas pieredze}

Turpinot ritināt trimdas pavedienu saistībā ar valodu un tās lietojumu ārpus Latvijas, valodniece Baiba Metuzāle-Kangere (2019) sniedz ieskatu valodas attīstībā trimdā līdz 1991. gadam. Tā kā šis iepriekšējais no Latvijas izcelı lojušo valstspiederīgo vilnis bija ievērojami liels - ap 200000 - un ārpus Latvijas pavadītais laiks ieilga daudzu gadu garumā un vairākās paaudzēs, ir vērts to ņemt par pamatu pašreizējās diasporas pētniecībai. Trimdas latviešiem, dzīvojot nošķirtiem no Latvijas (Latvijas PSR), izveidojās tāda situācija, ka latvietība un valoda, kas tika uzturētas trimdā, bija, kā dēvē B. Metuzāle-Kangere, "valoda bez valsts". Trimdā dzīvojošie latvieši turpināja "savu dzīvi kā minoritāt(es) svešās mītnes zemēs, kuras vinus integrēja savas valsts iekārtā,

${ }^{12}$ Lulle 2019, 225.

13 Zelče 2011. pakḷaujot latviešus asimilācijas procesiem"14. Viña atzīst, ka mācības, kas gūtas, var noderēt Latvijas valsts attīstībā arī mūsdienās. Īpaši valodas uzturēšanas zin̄ā vērts skatīties, kā situācija attīstîjās trimdā, lai varam vilkt paralēles ar to, kas notiek diasporā pašlaik.

Trimdas sabiedrība, kas izveidojās atsevišķās valstīs, kuras uzņēma bēgḷus no Latvijas, faktiski uznēma Latvijas valsts piederīgos, kuri vairākus gadus bija pavadījuši DP (DP - Displaced Persons) (t. s. dīpīšu) nometnēs, kas bija kā "Mazās Latvijas" - ar aktīvu sabiedrisko dz̄ivi, skolām, pat universitāti. Nokḷūstot jaunajās mītnes zemēs, trimdinieki turpināja veidot paši savu "Mazo Latviju", aktīvi pašorganizējoties un dibinot biedrības, organizācijas, skolas, un attīstīt citas pašdarbības iniciatīvas, kas, protams, veicināja latviešu valodas saglabāšanos vismaz pirmajā iebraukušo latviešu paaudzē.

Bet, par spīti latviešu trimdinieku aktīvai darbībai gan kultūras sfērā, gan latviešu valodas uzturēšanas jomā, laiks tomēr darīja savu un asimilācija bija manāma kā dabiska parādība, paaudzēm nomainoties laika gaitā.

B. Metuzāle-Kangere, aprakstot latviešu valodas situāciju jau agrajos gados trimdā, norāda:

Bažas par latviešu valodas izzušanu radās jau pirmajā posmā, kad atklājās, ka divvalodīgie bērni nerunā tik 〈tīri〉 kā vinnu vairāk vai mazāk vienvalodīgie vecāki. Vispār sāka valdìt uzskats, ka, ja nav pabeigta gimnāzijas izglītība Latvijā, tad cilvēku nevar uzskatīt par labu latviešu valodas pratēju. Vēlāk pieḷāva arī gimnāzijas beigšanu Vācijas nometnu skolās par kritēriju labai latviešu valodas prasmei. Daudzi tā laika 'vecās paaudzes' latvieši nesaredzēja iespēju noturēt dzīvu un spraigu latviešu valodu, vērojot izmainas nākamās paaudzes valodā. (Metuzāle-Kangere 2019, 112)

Trimdā tika dibinātas latviešu nedēlas nogales skolas, kas trimdas sākuma gados (50. gados) bija domātas tām trimdinieku atvasēm (trimdas 2. paaudzei), kuru mājas valoda ǵimenē bija latviešu valoda. Ar laiku, arvien pieaugot jauktām laulībām, mājas valoda daudzās ǵimenēs jau vairs nebija tikai latviešu

${ }^{14}$ Zelče 2011, 108. 
valoda. Ja valoda tika lietota, tad nākamajā paaudzē tā vairs nebija dzimtās valodas $\overline{1}^{-}$ men̄̄ - labākā gadījumā tā bija otrā, ǵimenē mazāk lietotā valoda. B. Metuzāle-Kangere:

Latviešu valodas runātāju skaits saruka, veidojoties apziņai, ka runātāja mìtnes zemes valodā var neaprobežoti izteikties, bet latviešu valodā uz katra soḷa jālauza galva un nereti pūles nevainagojās ar dailırunīgu, koptu, pat ne vienmēr ar pareizu latviešu valodu. (Turpat, 119)

Nav zināms, vai tajā laikā trimdā ir veikti empīriski pētîjumi gan par to, kā paši trimdinieki vērtējuši savas latviešu valodas prasmes, gan arī par trimdas latviešu valodas runas variantiem. Tomēr ir vērts pieminēt, ka, trimdai formāli beidzoties 1991. gadā, kad Latvijas neatkarība tika atjaunota, divu paaudžu laikā latviešu valoda nebija izmirusi. Latviešu valoda tomēr turpināja pastāvēt vēl trešajā paaudzē, un tā vēl tika lietota ikdienā trimdas pēcteču ǵimenēs valstīs, kur vēl darbojās trimdas kopienas.

2014. gadā tika aptaujāti ārpus Latvijas dzīvojošie otrās paaudzes bilingvālie bijušie trimdas skolu audzēknii ${ }^{15}$. Aptauja bija pieejama tiešsaistē, kā arī izplatīta trimdas latviešu plašsaziņas telpā, un uz to atsaucās 344 personas (lielākoties no ASV un Austrālijas, kā arī Kanādas, Lielbritānijas, Zviedrijas un Vācijas), kas apmeklēja latviešu skolu trimdā starp 1950. un 1991. gadu. Vairums (50\%) latviešu skolu trimdā bija apmeklējuši 70. gados. Tieši par valodu runājot, 91\% respondentu pārliecinoši vai drīzāk piekrita, ka skolas apmeklēšana ir uzlabojusi viņu latviešu valodas zināšanas. 92\% respondentu tomēr apzinājās, ka valodas prasme attīstījās, galvenokārt runājot latviski mājās, un $76 \%$ respondentu konstatēja, ka latviešu skola pozitīvi iespaidoja viņu valodas zināšanas. Tieši skatoties uz pašvērtējumu, respondenti paši savu latviešu valodas prasmi novērtēja kā samērā augstu (saprašana - 86\% tekoši, runātprasme - $76 \%$ tekoši, lasītprasme $-71 \%$ tekoši, rakstītprasme $-63 \%$ tekoši). Subjektivitātei šeit gan ir nozīme, toties tā apliecina, ka respondenti augstu vērtē savas saziṇas spējas latviešu valodā. Jautāti, vai viṇi

15 Grosa 2014 savus bērnus -3 . paaudzi - ved vai ir veduši uz latviešu skolu, $65 \%$ atbildēja pozitīvi, $28 \%$ negatīvi, un $6 \%$ (bijušie trimdinieki) dzīvo Latvijā.

Jāņem, protams, vērā, ka aptaujas respondenti, atsaucoties uz aicinājumu piedalīties aptaujā, paši aktīvi vēl seko latviešu plašsaziņas līdzekḷiem un sociālajiem tīkliem un turpina izrādīt interesi par latvietību - citādi viņi par aptauju nebūtu uzzinājuši. Tomēr ir vērts pieminēt, ka valodas un kultūras uzturēšana, kaut mazam procentam, vēl turpinās 3. un dažkārt pat 4. paaudzē un šis ǵimenes vēl aktīvi darbojas trimdas sabiedrības struktūrās un uztur tradīcijas, kas pārmantotas no iepriekšejāam trimdas paaudzēm. Turklāt, sākot ar 1991. gadu, trimdas sabiedrībai pamazām pievienojās no Latvijas izbraukušais jaunais emigrantu vilnis, kas ienesa svaigas asinis un nereti atdzīvināja vietām jau stipri panīkušu sabiedrību, un iedvesa jaunu elpu.

Vai raksta sākumā pieminētajos pētījumos par diasporu tiešām paveras sociolingvistes Inas Druvietes agrāk pieminētā aina - proti, ka pasaules valodu zuduma "galvenais iemesls ir vecāku un vecvecāku nespēja vai nevēelēšanās nodot savu valodu nākamajām paaudzēm"?

\section{Diasporas pētniecība}

Migrācijas pētnieku secinājumos par Latvijas diasporu šobrīd atklājas valodas zināšanu un lietošanas dinamika, un 2019. gadā iegūtie dati ir gan analizējami paši par sevi, gan arī longitudināli salīdzināmi ar 2014. gada datiem $^{16}$.

Pie ārvalstīs dzīvojošiem Latvijas valsts piederīgajiem pieskaitāmi gan etniskie latvieši, krievu tautības emigranti, kā arī mazs procents citu tautību emigrantu - kopumā skatoties, visi ārvalstīs dzīvojošie latvieši un Latvijas valstspiederīgie tiek saukti par Latvijas diasporu. Dati, kas tiek apkopoti aptaujā, ir n,emti no diasporas respondentu pašvērtējuma par savām un savu bērnu valodas spējām. Pētījuma dati rāda, ka kopumā 72\% (salīdzinājumā ar 59\% 2014. gadā) Latvijas diasporas pārstāvju paši savas latviešu valodas zināšanas vērtē kā "ḷoti labas vai pārvaldu brīvi". Skatoties uz

16 Mieringa et al. 2020. 
diasporu griezumā pēc tautības, 86\% latviešu, 51\% krievu un $62 \%$ citu tautību diasporas pārstāvju pārvalda latviešu valodu brīvi. Datus ietekmē pāris faktoru, kā, piem., krievu tautības emigrantiem ir uzlabojušās latviešu valodas prasmes, vai arī fakts, ka latviešu valodu individuālie respondenti ir uzlabojuši tāpēc, ka viṇi plāno tuvākā nākotnē atgriezties Latvijā.

Pēc etniskās piederības otrs būtiskākais faktors, pēc kura tiek noteiktas latviešu valodas zināšanas, ir latviešu valodas lietošana gimenē. Izrādās, ka valodas lietojumu ǵimenē neietekmē fakts, ka dzīvesbiedrs ir sveštautietis, - būtiski ir tas, vai latviešu valoda ǵimenē tiek lietota ikdienā (arī ja tā tiek lietota līdztekus citai valodai). Ārpus Latvijas pavadīto gadu skaits arī ir viens no ietekmējošiem faktoriem. Valodu var sākt aizmirst arī tie diasporā dzīvojošie, kuri dzimuši un auguši Latvijā, ne tikai vinu bērni. Respondentiem ar Latvijas pilsonību ir labākas latviešu valodas zināšanas, tātad simboliskā saikne ar Latviju pamudina uzturēt valodas prasmes.

Ielūkojoties, kādas ir diasporā visplašāk izplatītāko valodu - anglu un krievu valodas zināšanas, pētījumā atklājas, ka angḷu valodas zināšanu līmenis 2019. gadā ievērojami uzlabojies salīdzinājumā ar 2014. gadu: pirmā emigrantu viḷna pētījumā no visiem respondentiem $74 \%$, bet otrā viḷna pētījumā jau $78 \%$ angḷu valodas zināšanu pašvērtējums bija "loti labas / dzimtā vai labas". Krievu valodas zināšanās parādās pretēja aina - salīdzinot atbildes, kas saņemtas reizi piecos gados, visiem respondentiem neatkarīgi no tautības krievu valodas zināšanu pašvērtējums "loti labas / dzimtā vai labas" samazinājies no 77\% līdz 67\%.

Šis angḷu valodas zināšanu līmeña pieaugums un krievu valodas zināšanu līmeņa kritums ir dabisks, ja ǵimenē un ikdienā tiek vairāk vai mazāk izmantotas katra no šīm valodām. Jo ilgāks laiks tiek pavadīts ārpus Latvijas, jo lielāka valodu izmaiṇu tendence.

Sarunu valoda mājās ḷoti ietekmē diasporas locekḷu valodas prasmju uzturēšanu vai lejupslīdi. 2019. gadā 46\% respondentu diasporā lieto latviešu valodu, 46\% anglu valodu, 38\% krievu valodu, $13 \%$ mìtnes zemes valodu (ne angḷ valodu vai krievu), 2\% runā vēl kādā citā valodā. Salīdzinoši 2014. gadā latviešu valodu lietoja $42 \%$, krievu $46 \%$ un kādu citu valodu 39\% respondentu (anglu valoda nav atdalìta no citām valodām).

Aina gan paveras mazliet citādāka, ja skatās tikai latviešu tautības respondentu gímeņu saziņas valodu, jo kopš 2014. gada ir palielinājies (no 24\% līdz 32\%) to cilvēku skaits, kas gimenē lieto gan latviešu, gan kādu citu valodu. Būtiski ir samazinājies (no 40\% līdz $28 \%$ ) to ǵimeṇu skaits, kurās latviešu valoda ir ǵimenes saziṇas valoda. Šāda krituma dēl latviešu valodas saglabāšana ǵimenē ir manāmi apgrūtināta.

Ieskatoties valodas dinamikā individuālā līmenī un salīdzinot 1073 respondentu (kuri aptaujas aizpildīja abos pētījumos) sniegtos datus pa gadiem (2014 un 2019), atklājas, ka $19 \%$ respondentu, kuri iepriekš latviešu valodu lietoja gimenē, 2019. gadā to vairs nelieto, kurpretim 12\% sākuši lietot latviešu valodu.

Faktori, kas ietekmē izmainas valodas lietošanā, - citā valodā biežāk runā, ja ir vēlme turpināt dzīvot ārzemēs. Latviski vairāk runā, ja bieži ciemojas Latvijā. Ja respondents regulāri sazinās ar ǵimeni/draugiem Latvijā, tad arī gimenē latviešu valodu lieto vairāk. Ja biežāk uzturas latviešu valodas vidē (šeit var arī pieskaitīt diasporas latviešu aktivitātes/ pasākumus), tad ir arī lielāka iespēja, ka ieradums iesaknosies ǵimenē.

Pētījumā arī tika izgaismots fakts, ka valodu zināšanas ir viens no būtiskiem faktoriem, kas ietekmē plānus palikt emigrācijā vai remigrēt. Kopumā 19\% visu respondentu uzskata, ka grūtības latviešu valodas apgūšanā ir šķērslis, kas kavē atgriezties Latvijā, un, salīdzinot ar 2014. gadu, šis procents ir palielinājies. Turklāt $73 \%$ diasporas vecāku apgalvo, ka bērna iekḷaušanos skolā vai pirmsskolā Latvijā traucētu bērna latviešu valodas zināšanu lìmenis.

Respondentiem atbildot par savu nepilngadīgo bērnu latviešu valodas prasmēm, atklājās, ka vairāk nekā 50\% Latvijas diasporas bērnu (arī krievu un citu tautību respondentu bērnu) latviešu valodas zināšanas ir "vājas", "loti vājas" vai "nekādas". Veicot regresiju analīzi, pētnieki secināja, ka galvenais faktors, kas iespaido bērna latviešu valodas zināšanas, ir latviešu valodas lietošana ǵimenē. Vecāku motivācija un patriotisms vai piederības sajūta Latvijai ir viens no noteicošiem faktoriem - bez 
vecāku dzinuļa valodas apguve nenotiks vai būs ḷoti minimāla.

\section{Intervijas ar diasporas pārstāvjiem sniedz dziḷāku ieskatu}

Šobrīd Latviešu valodas aǵentūras uzdevumā tiek veikts pētījums par latviešu valodas lietošanu diasporā. Gan Eiropā, gan ārpus tās pētījuma ietvaros ir veiktas padziḷinātas intervijas ar ǵimenēm, kurās latviešu valoda tiek uzturēta gimenē. No respondentiem pētnieki uzzina par valodas lietošanas paradumiem ikdienā ǵimenē, kā arī par dažādiem citiem veidiem, kā latviešu valodas lietošana tiek veicināta diasporas ǵimenēs. Padziļinātās intervijās atklājas respondentu viedoklis par valodas lietošanu un uzturēšanu daudz sīkākās niansēs, nekā iespējams uzzināt tiešsaistes aptaujā.

Tā, piem., kādā intervijā atklājas valodu lietošanas aina ikdienā. Abi vecāki ir no Latvijas, Lielbritānijā dzīvojuši 10 gadus, divi vecākie bērni pirmsskolas vecumā pārcēlušies uz Lielbritāniju ar vecākiem, jaunākais bērns dzimis Lielbritānijā. Abiem vecākiem angḷu valodas zināšanas, kā saka pats respondents, ir basic līmen̄̄ - labā sarunvalodas līmenī. Atbildot uz jautājumu par to, kādā valodā ǵimenē runā mājās pie vakariņu galda, viņš saka:

Es nezinu. Es vakarin̄ās esmu baigi maz mājās, es esmu pārsvarā darbāa. Tur jau ir tā lieta, ka sāk runāt latviski, bet tad ir uz pauzes, kaut ko nesaprot, un tad mēs pārejam uz angḷ valodu, bet mēs ar sievu cenšamies latviski runāt. Vinas jau klausās, un tad prasa, kas tas par vārdu bija, ko tas nozìmē. Nav tā, $k a$ vinas ir vienaldzìgas pret valodu. Ir $50 \mathrm{uz}$ 50. Man jau arī kaut kā automātiski aiziet, un arī runāju angliski reizèm, jo 10 gadi tomēr ir 10 gadi. Kaut kādas pēdas tajā valodā tas atstāj. Es arī runāju latviski, bet iestarpinās kaut kādi anglu vārdi iekšā, un to paliek arvien vairāk. (Respondents A, 10 gadus dzīvo Lielbritānijāa)

Savukārt cita aina paveras kādā daudzvalodu ğimenē. Respondente dz̄̄vo Polijā ar savu vīru cittautieti. Viniem ir trīs Latvijā dzimuši bērni (viens pilngadīgs, divi sākumskolas vecumā). Par valodu, kas tiek lietota pie vakariṇu galda, viṇa stāsta:
Mums ir loti interesanta lieta mājās. Restorānā bieži cilvēki nāk klāt un prasa, kādā valodā mēs runājam, jo mēs runājam visās trijās valodās pie galda. Respektīvi, ja runā bērni ar tēti, tad viņi runā angliski. Mēs varam pāriet uzreiz ar vīru krieviski, ja es kaut ko gribu iebilst iekšā. Ja es uzrunāju bērnus, tad es latviski ar viñiem runāju. Mēs visi varam diezgan labi pārmesties no vienas valodas uz otru. Principā mēs nepiedomājam pie tā. Tā mums ir - automātiski aiziet. (Respondente B, 3 gadus dzīvo Polijā)

Tātad ikdienā lietotā valoda nav pašsaprotama lieta - var notikt koda maiņa (code switching), kas var būt apzināta vai arī neapzināta, kā arī vienā sarunā katrs var runāt savā valodā un saprasties, vienam sarunu partnerim, iespējams, minimāli saprotot otra teikto.

Kad respondentei B uzdeva jautājumu "Vai Jūs esat apmierināta ar pašreizējām bērnu latviešu valodas prasmēm?”, viņas atbilde liecināja par rezignētību, bet tomēr cerību, ka viņas pūles valodas uzturēšanā nebūs veltas:

Protams, ka nē. Man vienu brīdi uznāca tāda filozofiska doma - kam to latviešu valodu vajag, jo es tos bērnus varbūt spiežu iet uz to latviešu skolinu, un vai tiem bērniem isti to valodu vajag? Tà kā nē. Laikam man to valodu gribas saglabāt, lai bèrni to zinātu. Tas ir no filozofiskā viedoklı, bet valoda, protams, ir mātes dzimtā valoda, un tie ir radinieki, kas tajā valodā runā. Jebkura valoda plusā, kuru tu zini, ir baigi labi un forši. Tas ir arī smadzenèm darbs, ja tu zini vēl vienu valodu. Tie ir plusi, kāpēc to valodu vajadzētu uzturēt un varbūt arī kaut kādā brīdì vairāk pamācìt kaut ko par garumzìmēm un kā tas viss lasās. Es domāju, ka tas ir tikai pluss, ja to varētu tā attīstīt. Protams, ir cits jautājums par laikiem un iespējām. Jā, es to gribētu. Tāpēc es arī sūtu savus bērnus pie omìtes un mēs mēginām kaut kā to visu saglabāt. (Respondente B)

Šì respondente, daloties savās pārdomās par to, kāpēc dzimtā valoda vispār jāmāca bērniem, atklāj savas iekšējās pretrunas; ka it kā, spriežot pēc loǵikas, valoda nav vajadzīga, bet, skatoties pēc emocijām, valoda jāzina gan saziņai ar radiem, gan kā papildu valoda. Jautāts par to, kas ir lielākie izaicinājumi, uzturot 
latviešu valodu ārpus Latvijas, respondents A atbild:

Šķērslis ir aiznemtība. Tu esi noguris. Sestdiena un svētdiena ir vienīgais laiks, kas tev ir no darba, ko tu gribi pavadìt savādāk tomēr. Man jau liels apbrīns ir tie vecāki, kuri dzìvo Anglijā un kuri tam velta laiku. Aplausi viniem! Man nav, es nevaru. Varbūt man liekas, ka vinas [meitas] nebrauks atpakal, uz Latviju un tur nestrādās, bet dzīvē viss var mainīties un sagriezties kājām gaisā. Viñas jau izlems beigās, kur un kā vinas dzīvos, bet valodu nekad nav par vēlu iemācìties. Viñas pabeigs universitāti te un varbūt brauks atpakal uz Latviju. Viñas jau zina, ka mācīsies valodu, bet vin,ām nav tā, ka vin,ām ir jāsāk no apalıs nulles. Viñām ir kaut kāda saprašana. Varbūt vin̄ām būtu jāsāk runāt, bet bērns jau kautrējas kaut ko pateikt. Ja pateiks kaut ko nepareizi, tad atkal kaut ko pārmetīs. Es nekad neesmu satraucies par valodu. Ja vinas gribēs, vin̄ām būs. Nav tā, ka mēs atbraucām uz Angliju un tagad tikai angliski runāsim bez neviena vārda latviski. Tā valoda ir. Varbūt tā nav dominējoša valoda gimene, bet tā ir. Man un sievai tā ir dominējošā valoda. Tas ipatsvars ir 60 pret $40.60 \%$ ir anglu valoda gimenē un 40\% - latviešu. (Respondents A)

Šajā situācijā latviešu valodai ir zināma loma dzīvē, bet galu galā dzìves neprognozējamības dēḷ pati izvēle latviešu valodu apgūt labākā līmen̄i tiek atstāta uz to brīdi bērnu dzīvē, kad tas būs nepieciešams. Latviešu valoda netiek uzspiesta, tā ir daḷa no ikdienas, bet otrā - mītnes zemes - valoda ǵimenē dabiski sāk n,emt virsroku, un šī dinamika tiek pieņemta kā pašsaprotama lieta.

Arī ja valodiskā vide visapkārt ir kā visaptveroša jūra, tomēr, izjūtot cieņu pret savu dzimto valodu, ar pozitīvu attieksmi var daudz ko panākt:

Tā anglu valoda diemžēl, es nevaru pat paskaidrot, kāpēc. Viña pārnem visu. Tas ir visās šūnās, tā anglı valoda nāk virsū, un uzturēt latviešu valodu [..] Es nezinu, es pat nezinu, ko es varētu vēl vairāk darìt. Bērniem arī ir dažādas spējas. Ir bērni, kam valodas nāk vieglāk un kam nenāk tik viegli. Viss kaut kas ir dzirdēts, kā trimdā gimenes ir uzturējušas ar kādām metodēm [..] Man ir robeža, ko es nedarǐ̌su, man ir savas metodes [..] Man brī̌ziem sirds lūst [..] Es kaut ko mèginu, bet es nezinu, ko es vēl reāli varētu izdarìt, lai savā jauktajā gimenē, kur man vīrs nav latvietis, uzturētu to latviešu valodu, lai netraumētu tos bērnus. Es gribu ar pacietību un mīlestību, es tiešām gribu pa labam. Un es ceru, ka pie$n \bar{a} k s$ tas brīdis, $k a$ vienā brīdì viniem tas būs svarīgi pašiem, ne tikai tāpēc, ka mamma liek, bet pašiem kaut kur iekšā nāks tā interese un velēšanās to uzturēt un uzlabot, jo, teiksim, ja tas bērns 18 gadu vecumā aizvāksies no manas mājas, ar mani kopā nebūs un ja viņš nolems, ka vinam to nevajag, tad tur nekas nebūs. Es ceru, ka varbūt ar kaut kādu mīlestìbu, ar saiknèm ar Latviju... Kas nu kuram svarīgi, ka viniem tas pašiem būs svarīgi tajā brīdì, kad es vairs nebūšu tā kā autoritāte, kas viniem saka, kas jādara. Tāds ir mans mērkis, kaut kā iedot varbūt to mīlestību, interesi un cien,u, ka viņi paši atrad̄̄s veidu, kā uzturēt, tā kā viniem pamati ir iedoti. (Respondente $\mathrm{D}$, dzīvo ASV, vīrs amerikānis, 3 skolas vecuma bērni)

Toties, atbildot uz jautājumu par valodu un identitāti "Vai latvietis var justies kā latvietis, ja viņš neprot latviešu valodu?", respondenta A atbilde liecina, ka teorētiski gan, viņaprāt, dzimtās valodas prasmes tomēr ir svarīgas, lai apliecinātu savu etnisko piederību:

Tad jau tu neesi latvietis, ja nesaproti latviešu valodu. Kā mēs zināsim, kas mēs esam, ja mums būs vienota valoda [Eiropā]? Ja Eiropā būs anglı valoda, tad tā būs nacionālā valoda un mēs eiropieši skaitīsimies. Tā ir mūsu identitāte. Latvietis ir latvietis, jo viņš zina latviešu valodu. Tas, kurš ir piedzimis un uzaudzis Latvijā, tam ir jāzina latviešu valoda. It ìpaši, ja tu dzīvo Latvijā, tas ir svarīgi. (Respondents A)

Ne visi respondenti piekrīt, ka latviskā identitāte ir saistīta ar valodu. Spānijā dz̄̄vojošā respondente $C$, atbildot uz jautājumu "Vai valoda ir svarīga latviskai identitātei?", par jaunāko, Spānijā dzimušo, bērnu, saka:

Vajadzētu pastāstīt par latviešu kultūru, lai viņš varētu justies kā latvietis nedaudz, ka viņam ir daḷa no tās Latvijas. Viṇš jau 
zina. Es puikam daudz ko stāstu par Latviju. Piemēram, ka latviešu valoda ir viena no visvecākajām valodām pasaulē. Es to stāstu ne tikai puikam, bet ari spāniem. Protams, viņi saka, ka tā nevar büt, bet es ar to l,oti lepojos, lai viņš vismaz justu, ka viņa mamma ir no tās puses, kur ir visvecākā valoda. Kādreiz es gāju uz skolu un stāstīju nedaudz par Latviju. Mums pat bija tāds Ziemassvētku pasākums kā piparkūku cepšana. Es mācīju bērniem piparkūkas cept... Bērniem tas ir tāds riktīgs wow! Tās piparkūkas ir piparotas - tā, lai izjūt! (Respondente C, 3 bērni, vairāk nekā 10 gadus dzìvo Spānijā)

Gan kvantitatīvie, gan kvalitatīvie dati apliecina, ka Latvijas valstspiederīgajiem, dz̄̄vojot diasporā arvien ilgāku laiku, mājsaimniecībā vai ǵimenē lietotās valodas dabiski piedzīvo valodas nomainuu (language shift). Individuālās ǵimenēs šîs izmainas ir pilnībā atkarīgas no latviski runājošā ǵimenes locekḷa etniskās pašapziņas, attieksmes pret latviešu valodu, kā arī no viedokḷa par to, vai latviešu valoda bērniem būs vajadzīga nākotnē. Dzīves nevaḷas un straujuma dēl, bieži vien arī noguruma dēl, pat neapzināti valoda var tikt lietota citā intensitātē, nekā, pēc pašu diasporas locekḷu domām, tā tiek lietota. Valodas lietošanas pašvērtējums ir viena lieta, pavisam cita lieta ir tas, kas notiek reālā dzīvē, mikrolīmenī.

\section{Secinājumi un ieteikumi}

Latviešu valodas lietošanas izmaiņas, no vienas puses, liecina par Latvijas valstspiederīgo un ārpus Latvijas dzīvojošo tautiešu atvērtību dzīvi dzīvot citādāk nekā viņu bērnībā. Dzīvojot Eiropas Savienībā ar tās savstarpēji atvērtām robežām, jārēḳinās ar daudzvalodību arī ǵimenē. Iespēja bieži ceḷot un samērā regulāri apciemot ǵimenes locekḷu izcelsmes valstis (gan mātes, gan tēva, ja gimene ir jaukta) diasporas nošķirtību no Latvijas tomēr mazina.
Saskarsme un saites ar tuviem radiem Latvijā ir atspaids valodas zudumam, kas citādāk notiktu vēl ātrāk.

Latvijas valsts piedāvātie dažādie atbalsta pasākumi diasporā dzīvojošām ǵimenēm valodas uzturēšanas, kultūras un pilsoniskās līdzdalības (etniskā pašlepnuma stiprināšanas) jomā stiprina Latvijas diasporas piederības sajūtu Latvijai, neskatoties uz to, ka diasporas dzīvesvieta var būt jebkura valsts pasaulē. Mobilitāte pasaulē un transnacionāls dzīvesveids ir jāuztver nevis kā izcelsmes valstu valodu zuduma nolemtība, bet drīzāk kā iespēja, kas diasporā dzīvojošajiem jānovērtē un jānodod tālāk.

Ang̣̦u valoda gan neapšaubāmi turpinās atstāt savu lielo ietekmi uz jebkuru diasporā mītošo ǵimeni, jo tā ir ne tikai globālā saziņas valoda darbā un gimenē, bet arī daḷēji netiešā veidā viens no bērnu izglītojošiem līdzekḷiem. No mazotnes, dzīvojot virtuālā vidē un ikdienā izmantojot dažādas platformas, lietotnes, mājaslapas, datorspēles, sociālos tīklus un citus tehnologiiju veidus, kas ir lielākoties pieejami tikai angḷu valodā, bērniem virtuālā vide spēelē lielu lomu viṇu neformālā izglītošanas procesā. Šì parādība, protams, nav tikai Latvijas diasporas īpatnība, tā ir redzama gan pašā Latvijā, gan visā pasaulē.

Nobeigumā, atgriežoties pie Diasporas likuma pantiem, kur latviešu valodas un kultūras saglabāšana diasporā tagad ir valsts likumā nosprausta kā viens no mērķiem, valstij attiecībā uz diasporu būtu vēlams joprojām atrast arvien jaunus ceḷus, kā Latvijas valsts piederīgajiem diasporā radīt interesi par Latvijas pozitīviem, pacilājošiem kultūras, izglītības un pilsoniskās līdzdalības pasākumiem gan virtuāli, gan klātienē tā, lai diasporā dzīivojošie tautieši caur arvien dažādākiem kanāliem justu saikni un piederības sajūtu Latvijai. Jo aktīvāka un plašāka būs diasporas iesaiste un līdzdarbība, jo lielāka būs vajadzība lietot latviešu valodu. 


\section{VĒRES}

Alba, R.; Logan, J.; Lutz, A.; Stults, B. (2002) Only English by the Third Generation? Loss and Preservation of the Mother Tongue among the Grandchildren of Contemporary Immigrants. Demography, 39, 3, $467-484$.

Diasporas likums. Latvijas Vēstnesis (14.11.2018.), 225. Pieejams: https://likumi.lv/ta/id/302998(09.09.2020.).

Druviete, I. (2016) Latviešu valoda pasaules sociolingvistisko procesu kontekstā. Valodas situācija Latvijā 2010-2015. Sociolingvistisks pētījums. Rīga : Latviešu valodas aǵentūra.

Fishman, J. (1972) The Sociology of Language. Rowley, MA : Newbury House.

Grosa, D. (2014) Trimdas skolu loma latviskās identitātes veidošanā un latviešu valodas mācīšanā no bijušo audzēkṇu skatpunkta. Latvija ārpus Latvijas. Kultūra, vēsture, emigrācija un nacionālā identitāte. Konferences referātu krājums. Rīga : Pasaules brīvo latviešu apvienība, 177-184.

Krauss, M. (1992) The world's languages in crisis. Language, 68, 1, 4-10.

Lee, R. (2018) Spousal Characteristics and Language Use at Home: Immigrants and Their Descendants in Canada. Sociological Perspectives, 61, 6, 874-893.

Linton, A.; Jimenez, T. R. (2009) Contexts for Bilingualism among US-born Latinos. Ethnic and Racial Studies, 32, 6, 967-995.

Lopez, D. (1996) Language: Diversity and Assimilation. Waldinger, R.; Bozorgmehr, M. (eds.) Ethnic Los Angeles. New York, NY : Russell Sage Foundation.

Lulle, A. (2019) Diasporas izpratne nesenās migrācijas procesos. Krišjāne, Z.; Krūmiñ̌̌, J. (zin. red.) Tautas ataudze Latvijā un sabiedrības atjaunošanas izaicinājumi. Rīga : LU Akadēmiskais apgāds.

Metuzāle-Kangere, B. (2019) Valoda bez valsts. Veisbergs, A. (red.) Valoda un valsts. Rīga: Apgāds "Zinātne".

Mierina, I.; Koroḷeva, I.; Saulītis, A. (2020) Valodas situācija Latvijā: 2016-2020. Pētījuma rezultāti. Rīga : LU Filozofijas un sociologijas institūts.

Stevens, G. (1985) Nativity, Intermarriage, and Mother-tongue Shift. American Sociological Review, 50, 1, $74-83$.

Valsts valodas likums. Latvijas Vēstnesis (24.09.1998.), 278. Pieejams: https://www.vestnesis.lv/ta/id/32854 (09.09.2020.).

Veltman, C. (1983) Language Shift in the United States. Berlin : Mouton.

Zelče, V. (2011) Migrācijas lielākās plūsmas. 19. gs. sākums - 1991. gads. Latvija. Pārskats par tautas attīistību 2010/2011. Nacionālā identitāte, mobilitāte un rīcībspēja. Rīga : LU Sociālo un politisko pētìjumu institūts, 49-63. 